\title{
Identification of Causes and Minimization of Delays in Highway Projects of Pakistan
}

\author{
SAMIULLAH SOHU*, ABDUL FATTAH CHANDIO**, AND KALEEMULLAH* \\ RECEIVED ON 10.10.2017 ACCEPTED ON 12.02.2018
}

\begin{abstract}
The problem of delay in construction industry is a regular phenomenon worldwide, and construction industry of Pakistan has no exception, particularly in highways projects. Delay can be described as the extension of time to complete the construction project. The aim of this paper is to identify main causes of delays in highway projects of Pakistan, and to determine mitigating measures for the identified causes. The research method of this study is based on literature review, questionnaire survey and semi structured interview. From in-depth literature review, twenty-six common causes of delay were found. A questionnaire survey was carried out among construction professionals of highway projects. The causes of delay in highways projects were ranked referring to their Mean values. A semi structured interview was carried out to determine mitigation measures for the top ten causes of delays. The data gathered from questionnaire survey was analyzed using SPSS (Statistical Package for the Social Sciences) while, data collected through semi structured interviews was analyzed using Nvivo software. The findings of this study are expected to be useful for construction parties, to mitigate the delays in highway construction projects of Pakistan.
\end{abstract}

Key Words: Construction, Highway Projects, Delays, Causes, Mitigation Measures.

\section{INTRODUCTION}

he timely completion of construction projects is
one of the most important aspect of projects
suc ss. However, delay is one of the main issues in construction industry [1]. According to Honrao et. al. [2] "construction delay is the difference between a project's original contract period at the time of bidding and its overall final contract period at the end of the construction project". Delay can results in many negative effects on construction project such as time overrun, cost overrun, low productivity, acceleration losses, contract termination, poor quality, and disputes among construction stake holders [3-4].

From the literature review it is observed that globally many construction projects face the issue of delays. Construction projects in developed countries like USA are also affected by delays [5]. Similarly, construction projects in UK also face the problem delays [6]. Moura et. al. [7] stated that $40 \%$ projects in Portugal construction industry experienced delay. Long et al. [8] interviewed 87

Authors E-Mail: (sohoosamiullah@gmail.com, fattahchandio@yahoo.com,kaleem9191@gmail.com)

* Faculty of Civil and Environmental Engineering, UniversitiTunn Hussein Onn Malaysia, Malaysia.

** Department of Electronic Engineering, Quaid-e-Awam University of Engineering, Science \& Technology, Nawabshah, Pakistan.

This is an open access article published by Mehran University Research Journal of Engineering and Technology, Jamshoro under the CC by 4.0 International License. 
construction experts, it was confirmed by the interviewees that delay is regular issue in Thailand construction projects. In Malaysia Endut et. al. [9] investigated the problem of delay in 359 sampled construction projects from both public and private sector. The findings of the study showed that in public sector only $20.5 \%$ projects were completed within specified time, while in private sector $33.35 \%$ projected were finished in scheduled time period. Falqui [10] studied delay in 2379 construction projects in Saudi Arabia and reported that almost 952 $(40 \%)$ of the projects suffered from delay. In Oman, Alnuaimi et. al. [11] conducted a survey in stakeholders of construction projects and concluded that almost $40 \%$ of the respondents agreed that their projects were affected by delay. Emam et. al. [12] examined the issue of delay in infrastructure projects in Qatar. Results of study showed that $80 \%$ of projects experienced delay with average range of $25 \%$. Mahamid [13] studied delay in construction projects in Palestine and found that $76 \%$ of the sampled projects suffered from delay. According to Omoregieand Radford [14] delay is a major problem in construction projects in Nigeria. Sambasivanand Soon [15] examined delay in Malaysian construction projects and reported that about $17.3 \%$ of the public projects experienced delay.

Like other countries, delay is one of the prime problem in construction industry of Pakistan. This is also confirmed by Sohu et. al. [16] that construction projects in Pakistan are facing the problem of delays, specifically in highway projects. Study carried out by Bangash [17], investigated delays in construction industry of Pakistan and revealed that majority of the projects were $11-30 \%$ delayed from their scheduled time.

Various studies have been carried out on construction delays and most of the studies focused on identifying factors of delay. However, little attention has been paid on mitigation measures for the identified causes. Further, causes of delay vary from country to country and compare to project types $[1,18]$. There is a strong need to explore the cause of delays in highways projects, and to find ways to cope with the problem of construction delays. Thus the objectives of this study are:

(1) To identify main causes of delay in highways project of Pakistan.

(2) To determine mitigation measures for the identified causes of construction delays.

\section{LITERATURE REVIEW}

Many researches were carried out on causes of delays in different types of construction projects and as a results a number of causes of construction delays were found in previous studies. Tafazzoli et. al. [5] investigated factors causing delays in construction projects of USA by conducting a nationwide survey and determined the critical level of 27 causes of delays. The results of the survey indicates that top causative factors of delays were modifications in the scope of project, delay in decision making, errors in design, delay in approval of design documents, unrealistic project schedule, poor communication among construction parties, delay in progress payment by the clients, inadequate contractor experience, poor site management, and mistakes in construction. Moura et. al. [7] detected most significant factors initiating delays in construction industry of Portugal, namely: financial problems of contractors, variation in prices of materials, and poor site supervision and management by the contractor. Kikwasi [3] indicated most important causes of delay in construction projects in Tanzania by carrying out a questionnaire survey among construction practitioners. The study findings showed that main causes of delay were frequent changes in design, delayed payment to suppliers, improper project management, lack of coordination among construction stakeholders involved in the project, and incompetent 
contractors. In Qatar, Emam et. al. [12] examined the factors which lad to delay in infrastructure projects. A questionnaire survey was conducted among 37 construction professionals involved in handling of infrastructure projects. The findings of the survey showed that main causes of delays are changes in design, ineffective planning and scheduling, changes in scope of project, under estimated project schedule, and shortage of skilledlabour. In Palestine, Enshassi et. al. [19] studied factors leading to delays in construction projects. A questionnaire was distributed to contractors, the results of the survey showed that main causes of delays were fluctuation in prices of materials, delay in materials supply to construction site, slow permits by local authorities, incompetent sub-contractors, and design changes. Shehu et. al. [20] conducted a field survey in 205 construction experts comprised of 105 consultants, 51 contractors, and 49 clients to identify causes of delay in Malaysian construction industry. The results of the survey showed that main five causes were financial problems faced by the contractor, delay in materials delivery, fluctuation in materials prices, unavailability of materials, and Unexpected site condition. In Vietnam, Long et. al. [8] looked at the causative factors of delays in large construction projects through quantitative approach. The study identified that most important cause of construction delays were, poor site monitoring, poor project management and financial problem of owners. Alinaitwe et. al. [21] investigated the factors of delay in public construction projects in Uganda, the findings of the study revealed that major three causative factors of delay were modifications to the scope of project, late payments, and deficient monitoring of site. Assaf et. al. [22] studied the factors leading to delay of large construction projects in Saudi Arabia, by circulating a questionnaire in construction practitioners. Analysis of the survey showed that main factors of construction delay were assigning contract to lowest bidder, insufficient project planning, financial problems of clients, variation orders, and unavailability of site workers.

Based on the above studies twenty-six common causes of delays in construction projects were identified, as listed below:

(1) Change in the scope of project

(2) Delay in decision making

(3) Errors in design

(4) Delay in approval of design documents

(5) Unrealistic project schedule

(6) Poor communication among construction parties

(7) Delay in payment by the clients

(8) Inadequate contractor experience

(9) Poor site management

(10) Mistakes in construction

(11) Financial problems of contractors

(12) Price variation of materials

(13) Poor site supervision and management

(14) Delayed payment to suppliers by contractors

(15) Poor project management

(16) Delay in materials delivery

(17) Shortage of materials,

(18) Un-expected site condition

(19) Slow permits by local authorities

(20) Lack of equipments

(21) Lack of consultant experience

(22) Financial problems of client

(23) Lack of experience of sub-contractor

(24) Inadequate experience of designers

(25) Poor contract management

(26) Labour absenteeism. 


\section{RESEARCH METHODOLOGY}

This study used combination of questionnaire survey and semi structured interviews to achieve two objectives of the study. The research method of this study is listed below:

A detailed literature review was carried out on construction delays, through which twenty-six common causes of delays in construction projects were identified. The identified common causes were used as a base for the design of questionnaire survey.

(2) A questionnaire was comprisesd of two sections, Section A and Section B. Section A was aimed to obtain general information of the survey respondents while, Section B included the causes of construction delays. A five point Likert Scale was used for determining significance level of causes of construction delays. The numeric values of likert scale were: 1 = "not significant" 2 = "slightly significant", $3=$ "moderately significant", 4 "very significant", And $5=$ "extremely significant".

(3) Pilot study was carried out, to check relevancy of causes of delays given in questionnaire to highway projects of Pakistan. Total thirty respondents participated in the pilot study. For relevancy of causes to highway projects, cutoff scale is adopted from Muhwezi et. al. [23] as presented in Table 1.

TABLE 1. CUT OFF SCALE OF CAUSES OF CONSTRUCTION DELAYS

\begin{tabular}{|c|c|}
\hline Mean Score & Level of Relevancy \\
\hline$<3$ & Non Relevant \\
\hline $3-5$ & Relevant \\
\hline
\end{tabular}

In the analysis of pilot study, the "mean values" of all causes of construction delays were above 3 , thus the causes listed in questionnaire were relevant to highway projects of Pakistan.

(4) After pilot study, the questionnaire was distributed to randomly 200 construction practitioners working in highway projects of Pakistan. However, total 140 questionnaires were received back, in which 130 were valid responses and considered for further analysis. The response rate for the questionnaire survey was $70 \%$. The demographic characteristics of the respondents for final questionnaire are shown in Table 2. The data gathered in questionnaire survey was analyzed using SPSS. "Mean Value" is used to rank the causes of delays in highway projects of Pakistan.

The mean score was calculated using SPSS software.

(5) Semi structured interviews, were carried out with non-randomly selected construction experts, in order to determined mitigation measures for the main ten causes of delays, which were identified by questionnaire survey. In this study, 15 interviewees were selected. The interviews were recorded using digital voice recorder. Later on data was analyzed with the help of Nvivo software. The detailed information of interviewees is presented in Table 3 .

\section{DATA ANALYSIS}

\subsection{Main Causes of Construction Delays}

For analysis of the questionnaire survey SPSS version 20 were used. The Cronbach's alpha coefficient $(\alpha)$ was used to check the reliability of collected data from questionnaire survey. The reliability test result is shown in Table 4. 
TABLE 2. INFORMATION OF INTERVIEWEES

\begin{tabular}{|c|c|c|}
\hline Respondent's profile & Responses & $\%$ \\
\hline \multicolumn{3}{|c|}{ Profession of Respondent } \\
\hline Client & 40 & 30.77 \\
\hline Contractor & 60 & 46.15 \\
\hline Consultants & 30 & 23.08 \\
\hline Total & 130 & $100 \%$ \\
\hline \multicolumn{3}{|c|}{ Education Level } \\
\hline Diploma & 42 & 32.30 \\
\hline Bachelor degree & 60 & 46.15 \\
\hline Master & 28 & 21.55 \\
\hline Total & 130 & $100 \%$ \\
\hline \multicolumn{3}{|c|}{ Working Experience } \\
\hline Less than 10 years & 25 & 19.23 \\
\hline $10-20$ years & 73 & 56.15 \\
\hline More than 20 years & 32 & 24.62 \\
\hline Total & 130 & $100 \%$ \\
\hline
\end{tabular}

TABLE 3. DEMOGRAPHY OF INTERVIEWEES

\begin{tabular}{|c|c|c|c|}
\hline Interviewee & Role & Organization & Working Experience in Years \\
\hline 1 & Director & Client & 25 \\
\hline 2 & Managing Director & Contractor & 20 \\
\hline 3 & Project Manager & Contractor & 24 \\
\hline 4 & Director & Client & 23 \\
\hline 5 & Managing Director & Contractor & 21 \\
\hline 6 & Resident Engineer & Consultant & 16 \\
\hline 7 & Project Engineer & Contractor & 18 \\
\hline 8 & Director & Client & 24 \\
\hline 9 & Resident Engineer & Consultant & 15 \\
\hline 10 & Project Manager & Contractor & 17 \\
\hline 11 & Deputy Director & Client & 20 \\
\hline 12 & Construction Engineer & Contractor & 10 \\
\hline 13 & Assistant Resident Engineer & Consultant & 10 \\
\hline 14 & Project Manager & Contractor & 22 \\
\hline 15 & Assistant Resident Engineer & Consultant & 12 \\
\hline
\end{tabular}


According to Wai et. al. [24] the Cronbach's alpha value should be higher than 0.7 , Table 4 shows that Cronbach's alpha is above 0.7 , thus the gathered data of questionnaire survey is valid. Table 5 shows the Mean Score of the causes of delays in highway projects, the causes have been assigned ranks in relation to their Mean Score.

TABLE 4. RELIABILITY STATISTICS

\begin{tabular}{|c|c|}
\hline Cronbach's Alpha & Number of Items \\
\hline 0.816 & 26 \\
\hline
\end{tabular}

TABLE 5. RANKING OF CAUSES OF DELAY IN HIGHWAY PROJECTS

\begin{tabular}{|c|c|c|}
\hline Causes & Mean Score & Rank \\
\hline Poor site management & 4.63 & 1 \\
\hline Inadequate contractor experience & 4.55 & 2 \\
\hline Poor communication among construction parties & 4.50 & 3 \\
\hline Price variation of materials & 4.48 & 4 \\
\hline Errors in design & 4.46 & 5 \\
\hline Improper planning & 4.42 & 6 \\
\hline Shortage of materials & 4.33 & 7 \\
\hline Poor contract management & 4.21 & 8 \\
\hline Slow permits by local authorities & 3.85 & 9 \\
\hline Change in the scope of project & 3.83 & 10 \\
\hline Delay in payment by the clients & 3.73 & 11 \\
\hline Financial problems of contractors & 3.71 & 12 \\
\hline Poor project management & 3.62 & 13 \\
\hline Unrealistic project schedule & 3.58 & 14 \\
\hline Delay in approval of design documents & 3.56 & 15 \\
\hline Mistakes in construction & 3.50 & 16 \\
\hline Un-expected site condition & 3.44 & 17 \\
\hline Delayed payment to suppliers by contractors & 3.42 & 18 \\
\hline Lack of consultant experience & 3.38 & 19 \\
\hline Lack of equipments. & 3.34 & 20 \\
\hline Financial problems of client & 3.32 & 21 \\
\hline Delay in decision making & 3.30 & 22 \\
\hline Delay in materials delivery, & 3.26 & 23 \\
\hline Lack of experience of sub-contractor, & 3.25 & 24 \\
\hline Inadequate experience of designers, & 3.06 & 25 \\
\hline Labour Absenteeism & 3.03 & 26 \\
\hline
\end{tabular}

Mehran University Research Journal of Engineering \& Technology, Volume 38, No. 1, January, 2019 [p-ISSN: 0254-7821, e-ISSN: 2413-7219] 


\subsection{Mitigation Measures for Main Causes of Delays}

Following the analysis of the questionnaire survey results, the mitigation measures for top 10 causes of delays were investigated by interviewing construction experts. Table 6 shows the mitigation measures for top 10 causes of delays, identified through thematic analysis of interviews data using Nvivo software.

TABLE 6. MITIGATION MEASURES FOR TOP CAUSES OF CONSTRUCTION DELAYS

\begin{tabular}{|c|c|}
\hline Causes & Mitigation Measures \\
\hline \multirow{4}{*}{ Poor site management } & Contractor should effectively handle unforeseen situations at site. \\
\hline & Proper monitoring of construction activities. \\
\hline & Develop good working calibration among site's staff. \\
\hline & Adequate training programs for staff working on site \\
\hline \multirow{3}{*}{ Inadequate contractor experience } & Select contractors having history of quality working. \\
\hline & Select contractors having history of timely completion of projects. \\
\hline & Establishing effective communication between contractor and client. \\
\hline \multirow{3}{*}{ Poor communication among construction parties } & Arrange seminars, which highlights partner's responsibility. \\
\hline & Construction stakeholders should participate in meetings. \\
\hline & Establish rules and regulation for communication among construction parties. \\
\hline \multirow{3}{*}{ Price variation of materials } & Using domestic materials. \\
\hline & Purchasing bulk of materials before starting construction activities. \\
\hline & Introduce effective contract with materials supplies. \\
\hline \multirow{3}{*}{ Errors in design } & Client should actively participate in design phase. \\
\hline & Appoint skilled design team. \\
\hline & Proper survey of construction site. \\
\hline \multirow{3}{*}{ Improper planning } & Before initiating project, client should plan strategically. \\
\hline & Adequate site visit before tendering. \\
\hline & Hire proficient staff at the planning section. \\
\hline \multirow{3}{*}{ Shortage of materials } & Establish good working relationship with material suppliers. \\
\hline & There should be proper communication between purchase and store sections. \\
\hline & Make possible proper estimate of required quantity of materials. \\
\hline \multirow{3}{*}{ Poor contract management } & Contracts should be granted on merit bases. \\
\hline & Hire experienced consultant. \\
\hline & Ensure contract documents are enough detailed. \\
\hline \multirow{3}{*}{ Slow permits by local authorities } & Make sure that project is complying with local authorities' development plan. \\
\hline & Submit all required documents to local authority on time. \\
\hline & Construction stake holders should maintain good working relationship with local authorities. \\
\hline \multirow{3}{*}{ Change in the scope of project } & Proper assessment should be done before starting project. \\
\hline & Climatic changes of site should be foreseen \\
\hline & Ensure effective communication between consultant and client at the design stage. \\
\hline
\end{tabular}

Mehran University Research Journal of Engineering \& Technology, Volume 38, No. 1, January, 2019 [p-ISSN: 0254-7821, e-ISSN: 2413-7219] 


\subsection{Discussion}

Analysis of the questionnaire survey results in determining top 10 causative factors delay in highway projects of Pakistan. Table 5, indicates that "poor site management" scored the highest mean value of 4.63 and ranked as a first cause of delay in highway projects. It was followed by "Inadequate contractor experience" and "poor communication among construction parties" which had 4.55 and 4.50 means scores respectively. Variation in prices of materials was ranked as fourth at 4.48 mean value while "errors in design" were ranked as the fifth cause of delays in highway projects of Pakistan.

Mitigation measures for top 10 critical causes were determined through interview sessions. For each critical cause a number of mitigation measures were determined. For most critical cause "poor site management" the mitigation measures were the following contractor should effectively handle unforeseen situations at site, proper monitoring of construction activities, develop good working collaboration among site's staff, and adequate training programs for staff working on sites. Similar for second critical cause "Inadequate contractor experience" the controlling measures was to select contractors having history of quality construction working.

\section{CONCLUSION}

This study concludes that delay is one the main issue in highway projects. Using a questionnaire survey, 26 causes in highway projects of Pakistan were identified. The main causes were poor site management, inadequate contractor experience and poor communication among construction stakeholders, price variation of materials, errors in design, improper planning, shortage of materials, poor contract management, slow permits by local authorities, and change in the scope of project. Semi structured interviews offered a rich source of information based on the experience of participants in relation to the controlling of delay causes. The findings of this study are envisioned to be useful contribution to construction industry of Pakistan, particularly highway projects, in mitigating delays.

\section{ACKNOWLEDGEMENT}

This research is carried with support from Faculty of Civil \& Environmental Engineering, UniversitiTun Hussein Onn Malaysia.The authors of this research are very thankful to the construction practitioners, who participated in this research.

\section{REFERENCES}

[1] Aziz, R.F., and Abdel A.A., "Exploring Delay Causes of Road Construction Projects in Egypt", Alexandria Engineering Journal, Volume 55, No. 2, pp. 1515-1539, 2016.

[2] Honrao, Y., and Desai, D.B., "Study of Delay in Execution of Infrastructure Projects", International Journal of Scientific and Research Publications, Volume 5, No. 6, pp. 1-8, 2015 .

[3] Kikwasi, G.J., "Causes and Effects of Delays and Disruptions in Construction Projects in Tanzania", Australasian Journal of Construction Economics and Building, Volume 1, No. 2, pp. 52-59, 2012. Aibinu, A.A., and Jagboro, G.O., "The Effects of
Construction Delays on Project Delivery in Nigerian
Construction Industry", International Journal of Project
Management, Volume 20, No. 8, pp. 593-599, 2002 .

Mehran University Research Journal of Engineering \& Technology, Volume 38, No. 1, January, 2019 [p-ISSN: 0254-7821, e-ISSN: 2413-7219] 
[5] Tafazzoli, L.A., and Shrestha, P., "Investigating Causes of Delay in US Construction Projects", 53rd Annual International Conference of the Associated Schools of Construction, Seattle, Washington, pp. 611-621, 2007.

Olawale, Y.A., and Sun, M., "Cost and Time Control of Construction Projects: Inhibiting Factors and Mitigating Measures in Practice", Construction Management and Economics, Volume 28, No. 5, pp. 509-526, 2010.

Moura, H.P., Teixeira, J.C., and Pires, B., "Dealing with Cost and Time in the Portuguese Construction Industry", CIB WorldBuilding Congress, pp. 1252-1265, Cape Town, South Africa, 2007.

[10] Falqi, I., "Delays in Project Completion: A Comparative Study of Construction Delay Factors in Saudi Arabia and the United Kingdom", Master Thesis, Heriot-Watt University, 2004.

[11] Alnuaimi, A., and Al-Mohsin, M., "Causes of Delay in Completion of Construction Project in Oman", International Conference an Innovations in Engineering and Technology, pp. 25-26, 2013.

[12] Emam, H., Farrell, P., and Abdelaal, M., "Causes of Delay on Infrastructure Projects in Qatar", 31stAnnual Association of Researchers in Construction Management Conference, pp. 773-782, Lincolnshire, UK, 2015.

[13] Mahamid, I., "Risk Matrix for Factors Affecting Time Delay in Road Construction Projects: Owners' Perspective', Engineering, Construction and Architectural Management, Volume 8, No. 6, pp. $609-617,2010$.
[14] Omoregie, A., and Radford, D., "Infrastructure Delays and Cost Escalation: Causes and Effects in Nigeria”, Proceedings of 6th International Postgraduate Research Conference, pp. 79-93, Delft University of Technology, Netherlands, 2006.

[15] Sambasivan, M., and Soon, Y.W., "Causes and Effects of Delays in Malaysian Construction Industry", International Journal of Project Management, Volume 25, No. 5, pp. 517-526, 2007.

[16] Sohu, S., Memon, N.A., Abbasi, S.A., Pahore, M.A., and Ullah, K., "Causes of Delay in Highway Projects in Pakistan”, 8th International Civil Engineering Congress on Ensuring Technological Advancement through Innovation Based Knowledge Corridor, pp. 35-40, Karachi, Pakistan, 2016.

[17] Bangash, Z.K., "Analyzing the Causes of Delays in Construction Projects for Peshawar: Contractor Perception”, Journal of Emerging Trends in Applied Engineering, Volume 1, No. 1, pp. 13-18. 2016.

[18] Kim, S., Tuan, K.N., and Luu, V.T., "Delay Factor Analysis for Hospital Projects in Vietnam”, KSCE Journal of Civil Engineering, Volume 20, No. 2, pp. 519-529. 2015.

[19] Enshassi, A., Kumaraswamy, M., and Al-Najaar, J., "Significant Factors Causing Time and Cost Overruns in Construction Projects in the Gaza Strip: Contractors' Perspective", International Journal of Construction Management, Volume 10, No. 1, pp. 35-60. 2010.

[19] Enshassi, A., Kumaraswamy, M., and Al-Najaar, J., "Significant Factors Causing Time and Cost Overruns in Construction Projects in the Gaza Strip: Contractors' Perspective", International Journal of Construction Management, Volume 10, No. 1, pp. 35-60. 2010.

[20] Shehu, Z., Endut, I.R., and Akintoye, A., "Factors Contributing to Project Time and Hence Cost Overrun in the Malaysian Construction Industry", Journal of Financial Management of Property and Construction, Volume 19, No. 1, pp. 55-75. 2014. 
[21] Alinaitwe, H., Apolot, R., and Tindiwensi, D., "Investigation into the Causes of Delays and Cost Overruns in Uganda's Public Sector Construction Projects", Journal of Construction in Developing Countries, Volume 18, No. 2, pp. 33-47, 2013.

[22] Assaf, S.A., and Al-Hejji, S. "Causes of Delay in Large Construction Projects", International Journal of Project Management, Volume 24, No 4, pp. 349-357, 2006.
[23] Muhwezi, L., Chamuriho, L.M., and Lema, N.M., "An Investigation into Materials Wastes on Building Construction Projects in Kampala-Uganda”, Scholarly Journal of Engineering Research, Volume 1, No. 1, pp. 11-18. 2012

[24] Wai, S.H., Ismail, S., and Ismail, S., "Exploring Success Factors of Social Infrastructure Projects in Malaysia", International Journal of Engineering Business Management, Volume 5. No. 2, pp. 1-9. 2013. 